\title{
Direct Electricity Production From Coconut Oil - The Electrooxidation Of Coconut Oil In An Acid Electrolyte
}

\author{
Paweł P. Włodarczyk ${ }^{1, *}$, Barbara Włodarczyk ${ }^{2}$, and Antonina Kalinichenko ${ }^{1}$ \\ ${ }^{1}$ Department of Process Engineering, University of Opole, Dmowskiego 7-9, 45-365 Opole, Poland
}

\begin{abstract}
Supplying more and more energy is an essential task of today's energy industry. In the last few decades, in addition to traditional methods of energy production, alternative energy sources have been developing at a fast rate. One of the devices that can use these sources is the fuel cell (FC). FCs can be a power source of the future mainly due to their high efficiency, their low impact on the environment and the possibility of powering with different fuels. Most often, FCs are powered by hydrogen. However, issues with its cheap production and storage are the reasons for seeking new fuels for FCs. Yet it must be a fuel that will provide a zero or low emission level. One of these fuels can be vegetable oil. The paper presents the measurements for the electrooxidation of coconut oil emulsion on a platinum electrode (with smooth surfaces). The electrooxidation was performed in an aqueous solution of $\mathrm{H}_{2} \mathrm{SO}_{4}$. Electrochemical measurements were performed in a glass cell with three electrodes. The obtained maximum current density was equal to $21 \mathrm{~mA} / \mathrm{cm}^{2}$. Therefore, there is a fundamental possibility of direct electricity production from coconut oil with acid electrolyte.
\end{abstract}

\section{Introduction}

Providing more and more energy is an essential task of today's energetic industry. Energy production is based on crude oil, coal, natural gas and nuclear energy. Yet, in the last few years renewable and alternative energy sources have also been developing at a fast rate. Devices which use renewable and alternative energy sources are solar collectors, photovoltaic cells, heat pumps, wind turbines or fuel cells (FCs). The last two devices have very high real efficiency $(40-80 \%)[1,2]$. Moreover, zero or low negative influence on the environment and silent operation is what characterizes FCs [3]. Fuel cells are primarily powered mainly by hydrogen $[1,2,4]$. However, problems with the storage of hydrogen are the reason for the search for new fuels for FCs, eg. crude oil, petroleum derivatives [5-7] or biofuels [8-11].

The current density is the most important parameter of FCs. The search for new catalysts for FCs is also very important to obtain high current density and lowering the costs of electrodes production [1-3, 12]; but first we must need to evaluate basic possibility

*Corresponding author: pawel.wlodarczyk@uni.opole.pl 
of the electrooxidation of a new fuel with a reference $(\mathrm{Pt})$ catalyst. Vegetable oil is an alternative fuel for Diesel engines and for heating with oil burners. One of these vegetable oils is coconut oil. The paper presents the electrooxidation of coconut oil with a Pt catalyst in an acid electrolyte at various temperatures and concentrations of oil.

Powering high efficiency power sources with renewable fuels will allow the development of devices using renewable energy sources and the elimination or reduction of toxic substances emissions. The FC is one kind of such a device used for electricity production.

The efficiency of a fuel cell is very high and can be calculated as: the change in Gibbs free energy divided by the change in enthalpy $[1,4]$. But, the relationship between Gibbs free energy in a theoretical cell and in a real cell shows that the Gibbs free energy in reality is always lower in real cell. So, the real efficiency of a fuel cell is always lower than the theoretical efficiency of a fuel cell.

The current density is the most important parameter of a fuel cell [12, 13]. The correlation between current density and overpotential is described by the Butler-Volmer exponential function [12]. But, in real conditions the choice of fuels for a particular catalyst must be confirmed by measurements. Unfortunately, despite extensive knowledge in the field of solid-state physics and the kinetics of catalytic reactions, the implementation of the catalysts is mainly carried out experimentally.

\section{Materials and method}

Coconut oil is an edible oil extracted from the kernel or meat of mature coconuts harvested from the coconut palm. It has various applications. Coconut oil can be extracted through dry or wet processing. Because of its high saturated fat content, it is slow to oxidize and, thus, resistant to rancidification. Coconut oil has been used in baked goods, pastries, and sautés, for hair grooming and more $[14,15]$. Coconut oil has also been tested for use as a feedstock for biodiesel to use as a diesel engine fuel [16-18]. In this manner, it can be applied to power generators and transport using diesel engines and more [19, 20]. Coconut oil is a solid substance at room temperature. For this reason it is necessary to maintain a temperature above $300 \mathrm{~K}$ to conduct measurements of coconut oil electrooxidation.

Coconut oil is a hydrophobic substance and does not conduct electric current. To cause conduction, an intermediate agent to dissolve coconut oil in water was used. Due to its excellent emulsification properties, Syntanol DS-10 was used as a detergent [21]. Syntanol DS-10 is a mixture of primary oxygen-ethylene-glycol ethers of fatty alcohol of $\mathrm{C}_{10}-\mathrm{C}_{18}$ fraction, and is characterized by high superficial activity, emulgation, dispersion, solubilisation capabilities [22, 23]. After electrooxidation of emulsion Syntanol DS-10 can be degraded, e.g. promoted by energy transfer reactions or by bacteria [24, 25]. Previous studies on the use of different oils used to produce electricity have shown that the use of this type of detergent gives real results $[5-7,10,11]$. The concentration of coconut oil was equal to $0.0025 \%, 0.0050 \%, 0.0100 \%, 0.0250 \%$ and $0.0500 \%$.

The investigated coconut oil emulsion was obtained by mixing, in various ratios of coconut oil, detergent and water, using a mechanical stirrer with a speed of about $1200 \mathrm{rpm}$. The emulsion stabilization time was approximately 2 hours. To obtain an emulsion, the coconut oil and emulsion was heated above the temperature of $300 \mathrm{~K}$ during mixing.

Measurements were according to the method of polarizing curves of coconut oil emulsion electrooxidation in a glass reactor, and on a smooth platinum electrode in an aqueous solution of sulphuric acid (aqueous solution of $\mathrm{H}_{2} \mathrm{SO}_{4}$ as electrolyte). Platinum was used as a catalyst of the working electrode due to its excellent catalytic properties [12]. The working electrode surface area was equal to $6.28 \mathrm{~cm}^{2}$. A saturated calomel electrode (SCE) was used as a reference electrode [26]. Research on the electrooxidation of the emulsion 
based on canola oil in acid electrolyte (aqueous solution of $\mathrm{H}_{2} \mathrm{SO}_{4}$ ), for various concentrations of canola oil and detergent, and at various temperatures $(303-348 \mathrm{~K})$ are presented in this paper.

Electrochemical measurements were performed in a glass reactor (glass cell) with a potentiostat (AMEL System 5000 apparatus) [10]. Figure 1 shows a diagram of the measurement position.

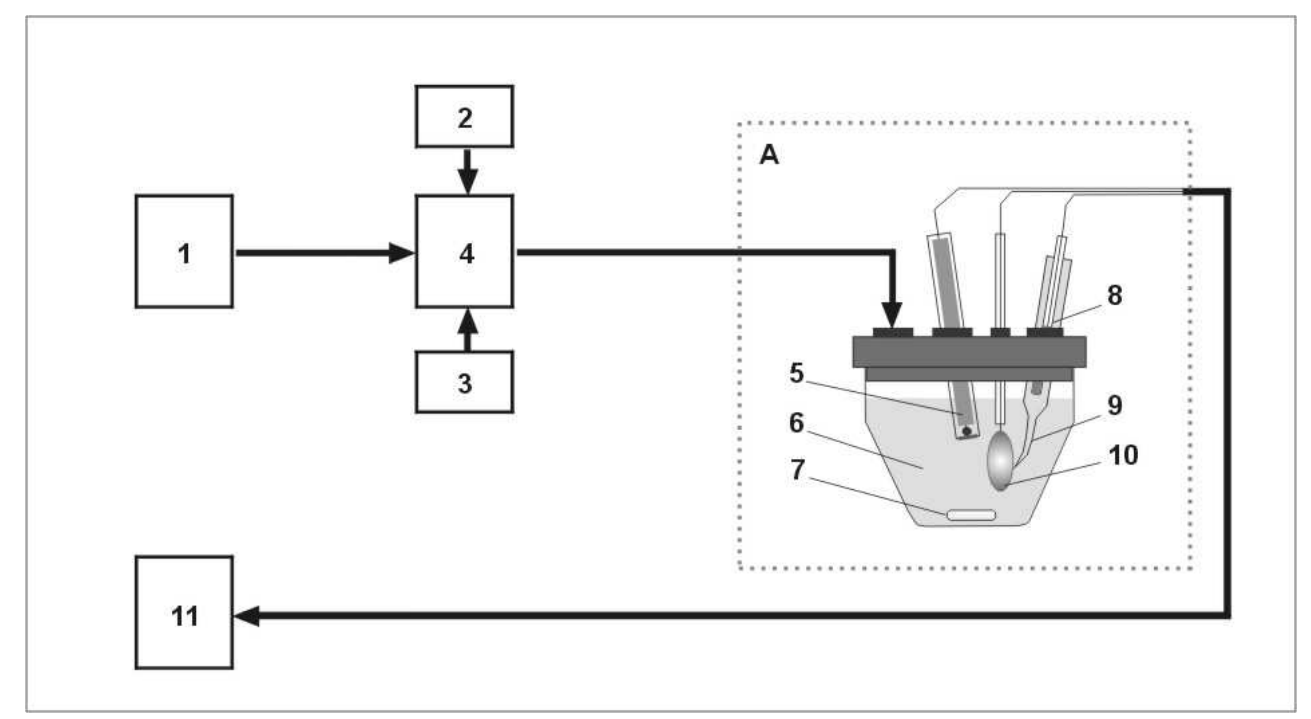

Fig. 1. Diagram of the measurement position; A - reactor (glass vessel) to measurements of emulsion electrooxidation 1 - coconut oil, 2 - water, 3 - detergent (Syntanol DS-10), 4 - coconut oil emulsion preparation (by mixing), 5 - auxiliary electrode, 6 - electrolyte (aqueous solution of $\mathrm{H}_{2} \mathrm{SO}_{4}$ ), 7 stirrer bar, 8 - reference electrode (SCE), 9 - Luggin capillary, 10 - working electrode $(\mathrm{Pt}), 11-$ data analysis.

First, measurements were taken for the electrooxidation of Syntanol DS-10 in an electrolyte (aqueous solution of $\mathrm{H}_{2} \mathrm{SO}_{4}$ ), for various concentrations of the detergent at temperatures ranging from $303-348 \mathrm{~K}$. Next, the measurements were taken for the electrooxidation of coconut oil emulsion in an aqueous solution of $\mathrm{H}_{2} \mathrm{SO}_{4}$ electrolyte, for various concentrations of the oil at temperatures ranging from $303-348 \mathrm{~K}$.

\section{Results}

The comparison of two processes:

- the electrooxidation of Syntanol DS-10,

- the electrooxidation of coconut oil emulsion,

allowed determining whether the electricity is generated from the electrooxidation of the oil, or only from the detergent. Figure 2-5 shows the electrooxidation of coconut oil emulsion in $\mathrm{H}_{2} \mathrm{SO}_{4}$ electrolyte at a temperature ranging from $303-348 \mathrm{~K}$. 


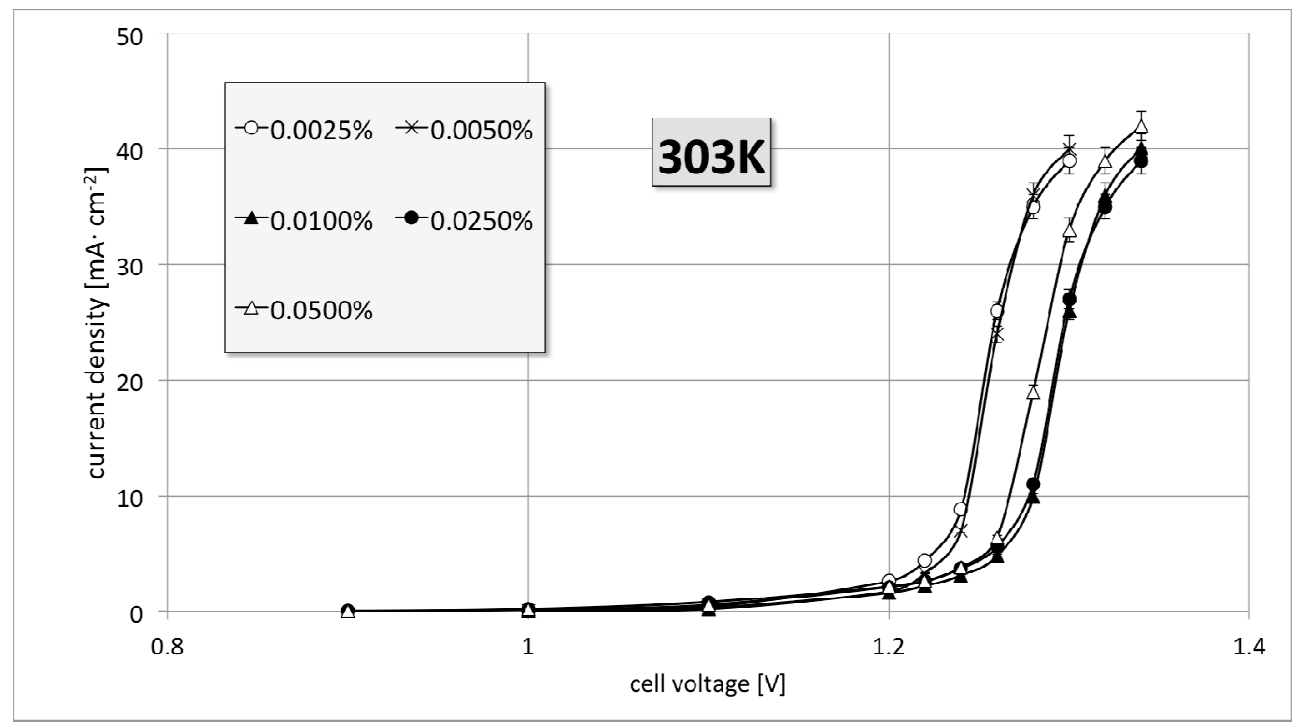

Fig. 2. Polarization curves of electrooxidation of coconut oil emulsion in $0,1 \mathrm{n}$ concentration of electrolyte $\left(\mathrm{H}_{2} \mathrm{SO}_{4}\right)$ at $303 \mathrm{~K}$ - the concentration of coconut oil was equal to $0.0025 \%-0.0500 \%$.

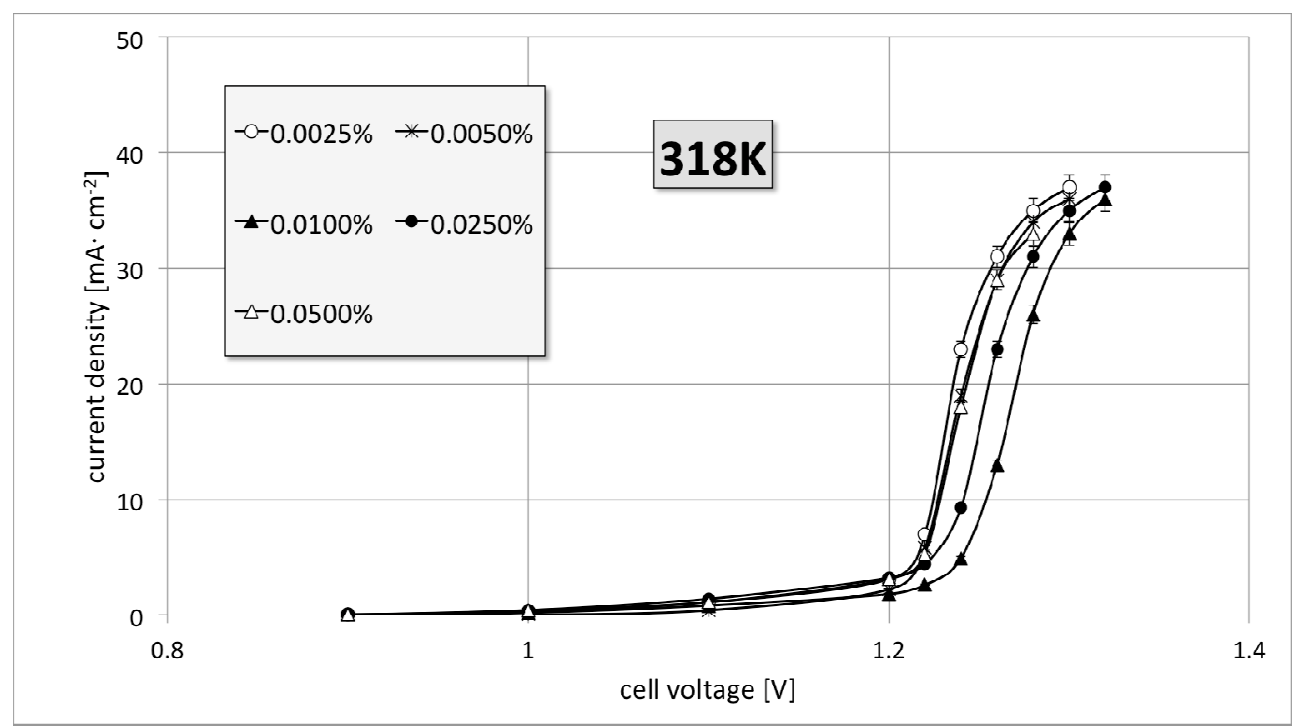

Fig. 3. Polarization curves of coconut oil emulsion electrooxidation in $0,1 \mathrm{n}$ concentration of electrolyte $\left(\mathrm{H}_{2} \mathrm{SO}_{4}\right)$ at $318 \mathrm{~K}$ - concentration of coconut oil was equal to $0.0025 \%-0.0500 \%$. 


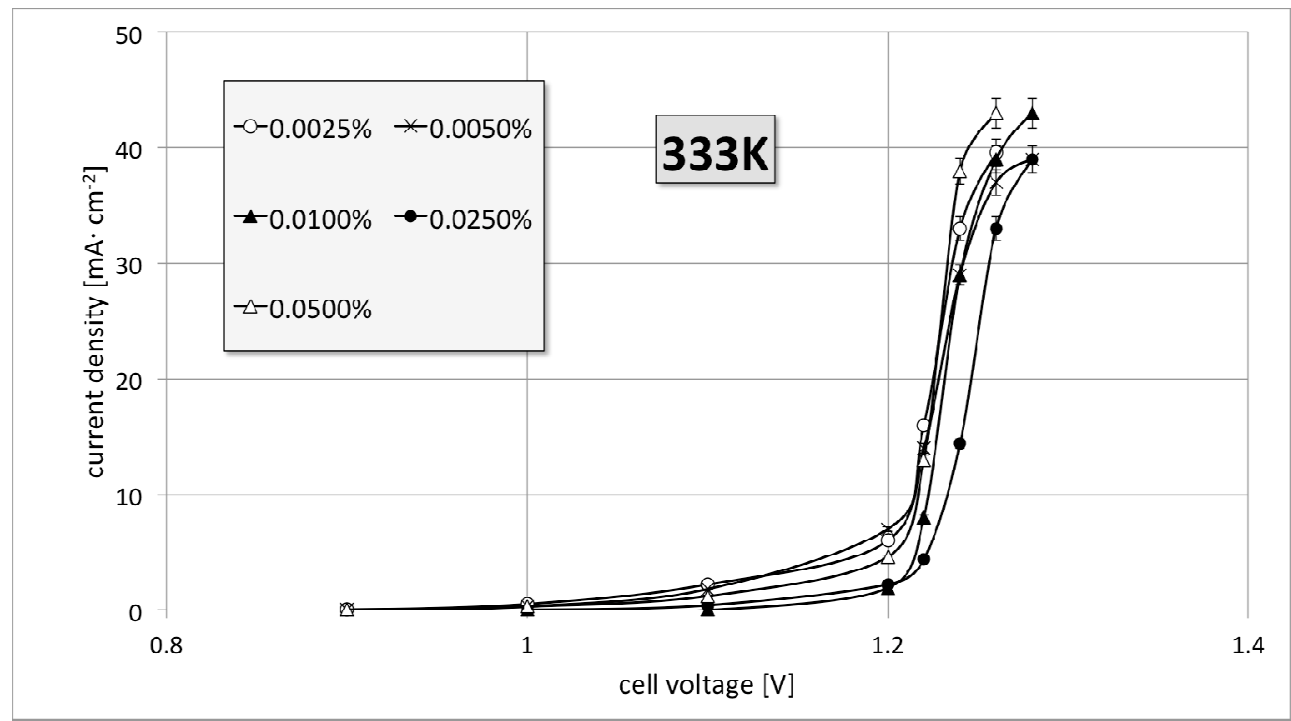

Fig. 4. Polarization curves of coconut oil emulsion electrooxidation in $0,1 \mathrm{n}$ concentration of electrolyte $\left(\mathrm{H}_{2} \mathrm{SO}_{4}\right)$ at $333 \mathrm{~K}$ - the concentration of coconut oil was equal to $0.0025 \%-0.0500 \%$.

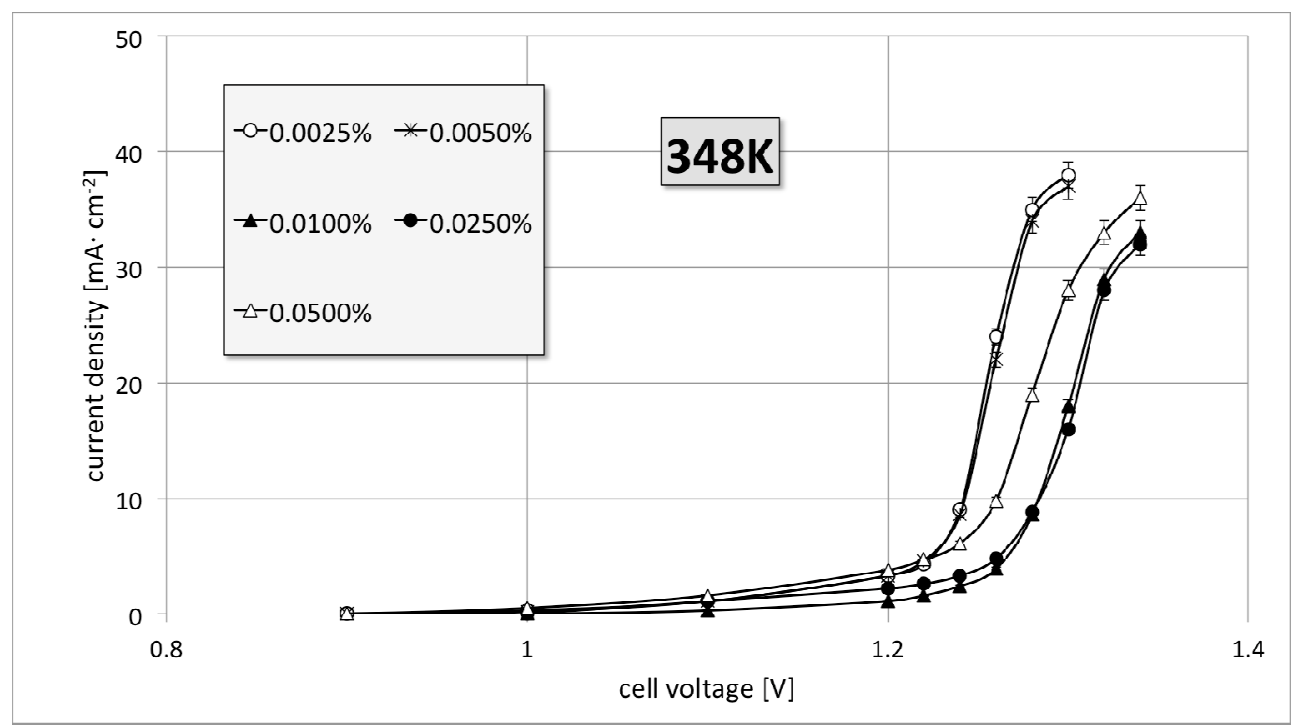

Fig. 5. Polarization curves of coconut oil emulsion electrooxidation in $0,1 \mathrm{n}$ concentration of electrolyte $\left(\mathrm{H}_{2} \mathrm{SO}_{4}\right)$ at $348 \mathrm{~K}$ - the concentration of coconut oil was equal to $0.0025 \%-0.0500 \%$.

The potential of a working electrode was established in about 20 minutes and was badly reproducible. Stationary, current-free real potential depends on coconut oil concentration and is included in the potentials range of $0.58-1.24 \mathrm{~V}$. These values are very close to the values obtained with, e.g. canola oil or waste canola oil $[10,27]$. To ascertain that the emulsion (and not only the detergent) was electrooxidated, measurements of the electrooxidation process run in the scope of kinetics, but the potential on the electrode is low and establishes in a long period of time. The electrooxidation of coconut oil emulsion occurred for all temperatures (303-343K), and for all concentrations of waste canola oil. 


\section{Conclusions}

Analysis of the data from the measurements has shown the validity of the research undertaken in order for using coconut oil for energy production without the process of combustion. The use of vegetable oil to generate electricity in fuel cells would allow developing the management of waste substances in a way that ensures low negative impact on the environment. The biggest difficulty was keeping the coconut oil emulsion at a constant temperature above $303 \mathrm{~K}$; because below this temperature the oil was solidified, and then precipitated from the emulsion.

A current density of about $6-15 \mathrm{~mA} / \mathrm{cm}^{2}$ was obtained for all concentrations of coconut oil. The highest results of current density $\left(21 \mathrm{~mA} / \mathrm{cm}^{2}\right)$ were obtained at the temperature of $333 \mathrm{~K}$. With a temperature above $348 \mathrm{~K}$, the first electrooxidation of Syntanol DS-10 takes place, and only then - for coconut oil emulsion. For this reason, ensuring the occurrence of the process of electrooxidation in fuel cells (with $\mathrm{H}_{2} \mathrm{SO}_{4}$ electrolyte) powered with emulsion of waste rapeseed oil, the temperature of $348 \mathrm{~K}$ should not be exceeded.

A fundamental possibility of electrooxidation of coconut oil emulsion on a smooth platinum electrode in acid electrolyte was shown in this paper. It has been demonstrated that using Syntanol DS-10 detergent to prepare the emulsion of waste canola oil allows for coconut oil electrooxidation, and thus enables direct conversion of coconut oil into electrical energy.

\section{References}

1. R. O'Hayre, S-W. Cha, W. Colella, F.B. Prinz, Fuel Cell Fundamentals (John Wiley \& Sons, Hoboken, 2005)

2. D. Stolten, Hydrogen and fuel cells. Fundamentals, Technologies and Applications (Wiley-VCH, Weinheim, 2010)

3. J. Larminie J., A. Dicks, Fuel cell system explained (John Wiley \& Sons Ltd., Hoboken, 2003)

4. G. Hoogers, Fuel Cell Technology Handbook (CRC Press, Boca Raton, 2004)

5. P.P. Włodarczyk, B. Włodarczyk, J. Power Techn., 93 (5), 394-396 (2013)

6. P.P. Włodarczyk, B. Włodarczyk, Infra. Ecol. Ruras Area, 4 (2), 1609-1618 (2017)

7. P.P. Włodarczyk, B. Włodarczyk, Inż. Ekol., 18 (1), 65-70 (2017)

8. J. Staniforth, R. M. Ormerod, Cat. Lett., 81 (1-2), 19-23 (2002)

9. H. Alves, C. Junior, R. Niklevicz, E. Frigo, M. Frigo, C. Coimbra-Araújo, Int. J. Hydrogen Ener., 38 (13) 5215-5225 (2013)

10. P.P. Włodarczyk, B. Włodarczyk, A. Kalinichenko, E3S Web of Conferences, 19 01019 (2017)

11. P.P. Włodarczyk, B. Włodarczyk, J. Eco. Eng., 18 (5) 173-179 (2017)

12. J. Bockris, A.K.N. Reddy, Modern Electrochemistry, Kulwer Academic/Plenum Publishers (2000)

13. W. Vielstich, A. Lamm, H. Gasteiger (eds.), Handbook of Fuel Cells: Fundamentals, Technology, Applications, Wiley-VCH (2003)

14. A.M. Marina, Y.B. Che Man, I. Amin, Trends in Food Sci. \& Technol. 20, 481-487 (2009)

15. A.S. Rele, R..B Mohile, - J. Cosmet. Sci. 54, 175-192 (2003)

16. M.A. Kalam, M. Husnawan, H.H. Masjuki, Renewable Energy, 28, 2405-2415 (2003) 
17. H. Machacon, S. Shiga,T. Karasawa, H. Nakamura, Biomass and Bioenergy, 20 (1), 63-69 (2001)

18. P. Nakpong, S. Wootthikanokkhan, Renewable Energy, 35, 1682-1687, (2010)

19. N.H. Jayadasa, K. Prabhakaran Nair, G. Ajithkumar, Trib. Intern. 40 (2), 350-354 (2007)

20. T. Mansor, Y. B. Che Man, Y. B., M. Shuhaimi, M. Abdul Afigq, F. Ku Nurul, Int. Food Res. J., 19 (3), 837-845 (2012)

21. Iu. I. Sakharov, E. G. Rastiannikov, G. M. Verbitskaia, L. N. Tarasova, Vopr Pitan., 4, 75-77 (1975)

22. O. Paraska, S. Karvan, Technical Transactions. Mechanics, Cracow University of Technology Press, 8 (107), 203-210 (2010)

23. A. Survila, Z. Mockus, S. Kanapeckaite, M. Samulevičienė, Electrochimica Acta, 50 (14), 2879-2885 (2005)

24. A.V. Kravchenko, A.G. Rudnitskii, A.F. Nesterenko, V.S. Kublanovskii, Ukrainian Chem. J., 60 (11), 1-13 (1994)

25. O.V. Ignatov, Iu.V. Shalunova, L.V. Panchenko, O.V. Turkovskaia, N.M. Ptichkina, Prikl Biokhim Mikrobiol., 31 (2), 220-223 (1995)

26. M. Holtzer M., A. Staronka, Chemia fizyczna (Wydawnictwa AGH, Kraków, 2000)

27. P.P. Włodarczyk, B. Włodarczyk, J. Power Techn., 96 (6), 459-462 (2016) 